\title{
Inflexive Marker and Morphophonological Processes in the Lamalera Dialect of Lamaholot Language (LDLL)
}

DOI: https://doi.org/10.47175/rielsj.v2i3.306

\author{
${ }^{1,2}$ Faculty of Teacher Training \\ and Education, Flores Ende \\ University \\ "nikaruing71@gmail.com / \\ yosefdemon86@gmail.com
}

| Yosef Demon ${ }^{1, *} \mid$ Veronika Genua²

\begin{abstract}
Inflection is a universal linguistic phenomenon. The phenomenon of inflection occurs in every language according to each language system. The language system of each language greatly determines the peculiarities of the language inflection. Inflection in a language that is agglutinative is different from that in a language that has a synthetic, tonal and isolating system. The treatment of each language is different for this case of inflection. Lamalera Dialect of Lamaholot Language (LDLL) also shows inflection. Inflection in $L D L L$ is different from inflection in other languages because of the language system, especially the LDLL sound system. LDLL is not characterized by agglutinative, nor synthetic, tonal nor isolating morphology. What is the strategy for inflection in LDLL? The result of the study shows that in LDLL, inflection is expressed clitically on the verb. These clitics are cross-referenced by the verbs. There are two types of cross-reference clitics, namely cross-referencing proclitics and enclitics. Proclitic cross-referencing applies to both transitive and intransitive root verbs. This form of crossreferencing pronouns is both proclitic and enclitic, and morphophonological changes actually occur. This process cannot be avoided because morphophonological processes actually occur due to merging of the morpheme with another morpheme. In this case the clitic is considered as bound morpheme.

KEYWORDS;
\end{abstract}

clitic; proclitic; enclitic; morphophonological.

\section{INTRODUCTION}

The language of the humankind is linked to the creation of meaning and expressions of human behaviors and emotions (Masorong, 2021). Inflection is a universal process of language. It is said that every language recognizes the existence of inflection. Although universally all languages recognize inflection, this does not mean that all languages are the same. Of course all languages have systematic peculiarities so that the inflection in each language differs according to the sound system of the language. Inflection is a morphophonological process that targets a morpheme. Assimilation is a phonological event (meeting of language sounds) which is caused by the relationship between arguments in a sentence. So the change occurs not because of the addition of affixes but more so because of the relationship between the arguments which calls for a phonological process. Lamalera Dialect of Lamaholot Language (LDLL) is not an agglutinative language, a language system that reflects a morphological form with a series of affixes. The Lamalera Dialect of Lamaholot Language reflects a morphological form with clitics (Demon 2006, Demon 2017). These inflectional clitics are be cross-referenced by verb predicates, both precategorial verb predicates and basic verbs. It is this pronoun intersection that cause a number of changes which are morphophonological events. 
The pronouns that are cross referenced are generally those which crossreference the function of the subject. Cross-referencing can be in the form of clitics that are attached in front of a precategorial verb which is commonly called proclitic, and crossreferencing clitics which are attached behind a verb are called enclitic. Precategorial verbs are incomplete verbs phonologically, morphologically, semantically and syntactically. In other words, precategorial verbs are verbs that do not have complete syntactic function. Proclitic verbs apply to precategorial verbs as well as basic verbs (transitive and intransitive). These attched clitics are bound morphemes. The addition of these bound morphemes both in front of and behind the verb causes changes.

The changes that occur in the morpheme in no way change the lexical identity of the morpheme. In a different opinion, the linguists state that 'Inflections are one type of grammatical morpheme, a morpheme that indicates a grammatical relationship' (Meyer, 2009:53).

The attached clitics, both proclitics and enclitics, are grammatical morphemes that show grammatical relations. In other words, Blake (1994:1-7) states that inflectional marking is a system for marking the type of relationship that dependents bear to their head. Inflectional marking is a system that shows the dependency relationship with the head and form a pattern (Matthews, 2000: 38). The change due to the pronominal cross-referencing of both precategorial and basic verbs is a morphophonological process. This mean that there is a phonological change in the morphological form. This morphological change turns the incomplete form into a complete morphological, syntactic and semantic form. This paper will examine inflectional markers and morphophonological processes in the Lamalera Dialect of Lamaholot Language. What is the LDLL strategy as a non-agglutinative language to deal with the formation of new morphemes?

\section{RESEARCH METHODS}

Data were collected using the listening and participation method, and keeping track of the communication of LDLL speakers. Apart from listening, data were also collected by chatting. Conversations were used to elicit speakers to express something using words that are altered by morphophonological processes. The data are then interpreted and analyzed using the induction-deduction or deduction-induction reasoning model.

\section{RESULTS AND DISCUSSION}

Inflected forms are forms of the same word, whose shapes differ according to their grammatical category (Chaer, 2007:171, Matthews, 2000: 38, Radfor, 2004:28). These different forms have a systematic inflectional pattern and show a close relationship with their grammatical function. There is a harmonious and systematic phonological pattern. Analyzing the data shows that the inflectional markers in LDLL are clitics. These clitic are a way of cross-referencing pronouns that function as the subject of the sentence. This form of cross-referencing includes both proclitic and enclitic cross-references. The form of proclitic cross-reference only applies to precategorial verbs, both transitive and intransitive precategorial verbs. Enclitic cross-reference forms apply to basic verbs, and to both transitive and intransitive root verbs.

The cross-referencing form of proclitic and enclitic are morphemes attached to the verb predicate (both precategorial and basic). The addition of clitics to each verb predicate is indicated by a morphophonological process.

The morphophonological process is a process of meeting between morphemes that causes changes in shape (Sumadi, 2012:142, Kridalaksana, 2009:183, Chaer, 2008:43, Parera, 2007:30). These are phonological events that play a role in morphological processes (Ino, 
2003:200). New words are formed by combining morphemes with other morphemes. The addition of clitics also causes morphological changes and semantic changes. The morphophonological process that occurs as a result of this cross-reference is the insertion of sounds such as the sounds $/ \mathrm{k} /, / \mathrm{t} /, / \mathrm{r} /, / \mathrm{l} /$ and $/ \mathrm{v} /$, replacement of sounds such as $/ \mathrm{g} /$ with $/ \mathrm{k} /$, sound $/ \mathrm{m} /$ with $/ \mathrm{k} /$, and zero changes. Semantically, the intersection of the numbers indicates intensity, especially in cross-referencing of intransitive root verbs.

Inflection involves the same word, but its form differs according to its grammatical category (Chaer, 2007:171, Matthews, 2000:38, Radfor, 2004:28). These different forms have a systematic inflectional pattern and show a close relationship with their grammatical function. There is a harmonious and systematic phonological pattern. Analyzing the data shows that the inflective markers in LDLL are clitics. These clitics crossreference the pronouns that function as the subject of the sentence. This form of crossreference includes both proclitics and enclitics. The cross-reference proclitics only attach to precategorial verbs, both transitive and intransitive precategorial verbs. Cross-reference enclitics attach to basic verbs, both transitive and intransitive root verbs. The proclitic and enclitic cross-reference forms are morphemes attached to the verbal predicate (eitherprecategorial and basic). The addition of clitics to each verb predicate indicated a morphophonological process. The morphophonological process is a process of Inflexive markers, and morphophonological processes in LDLL can be considered in the following description.

\section{Replacement (insertion) of the Initial Consonant and Sound Alternations}

1) Replacement (insertion) of Initial Sounds and Transitive Precategorial Verb Sound Changes Precategorial verbs are incomplete verbs phonologically, morphologically, syntactically and semantically. Phonologically incomplete means that the linguistic unit

does not sound complete as a unit that can stand alone. Incomplete morphologically means that the sound unit has not yet been formed as an independent linguistic unit. Syntactically incomplete means that the sound unit has not fully fulfilled its syntactic function as a verb predicate. Lamalera Dialect has a number of precategorial verbs. These precategorial verbs will be complete phonologically, morphologically, syntactically and semantically if they cross-refer using the clitic as shown in the following example.

\begin{tabular}{l} 
Example (1) \\
\begin{tabular}{|l|l|l|l|l|l|l|}
\hline Goe & ke & kluo & $k=e n u$ & vai & $k=$ ete & vata \\
\hline GoE & $k=\ddot{a}$ & kluo & $k=e n u$ & vai & $k=\partial t E$ & vata \\
\hline saya & makan & nasi & minum & air & bawa & jagung \\
\hline
\end{tabular} \\
'Saya makan nasi', 'Saya minum air', 'Saya bawa jagung' \\
\hline
\end{tabular}

Example (1) consists of three basic verbal sentences, namely Goe k=ä kluo 'I eat rice', Goe $k=e n u$ vai, 'I drink water', Goe k=əte vata, 'I bring corn'. The verb $k=\ddot{\partial}$ 'eat', $k=e n u$, 'drink' and $k=$ ste 'carry' are in the transitive (bivalent) category of precategorial verbs. Morphologically, these three kinds of precategorial verbs undergo very distinctive changes. These three transitive precategorial verbs become syntactically complete when they crossrefer using the pronouns that are in front or at the end.

This cross-reference causes morphophonological changes. The first-person singular pronouns are cross-referenced clitically and these clitics are attached to the front of the three precategorial verbs. This type of affix is called a proclitic. What is interesting about this case is the cross-reference which causes the morphophonological process. The first singular pronoun goe 'I' is cross-referenced with the clitic $k=$ so that it becomes $k=\ddot{\partial}$, 'I eat', $k=e n u$ 'I 
drink' and $k=\partial t e$ 'I take'. The sound of dorsovelar $/ \mathrm{g} /$ changes to dorsovelar $/ \mathrm{k} /$ and the vowel sound /a/ changes to nasal / $/ 2 /$. These changes occur due to the meeting of two different sounds in the formation of a new morpheme. The dorsovelar sound /g/ meets the vowel sound /a/ which should make $g=a$, not $k=\ddot{\partial}$. There was a sound change event, namely /g/ being replaced by $/ \mathrm{k} /$ and this sound replacement also changes the vowel sound $/ \mathrm{a} /$ into a nasal vowel /ä/. Of course the replacement of sound, whether the sound $/ \mathrm{g} / \mathrm{by} / \mathrm{k} /$ or the sound /a/ by /ä/ is a phonological event because there is a similarity in sound between the sounds that are replaced. For example, the sound $/ \mathrm{g} /$ and $/ \mathrm{k} /$ are both dorsovelar sounds, while the distinguishing feature is that $/ \mathrm{g} /$ is voiced while $/ \mathrm{k} /$ is not. Likewise, the vowel $/ \mathrm{a} /$ is replaced by /ä/ because they are both middle vowels, the difference is that the vowel /a/ is lower mid while the /ä/ vowel is mid. The sound /k/, /g/ and /a/ have another characteristic in common, namely that they are back sounds. Even though there is a replacement of sounds in forming a new morpheme, the resulting morpheme is still categorized as a verb so there is no change in word class or derivation.

Example (2)

\begin{tabular}{|c|c|c|c|c|c|c|}
\hline moe & $g=o$ & kluo & $m=e n u$ & vai & $m=e t e$ & Vata \\
\hline moe & $g=o$ & kluo & $m=e n u$ & vai & $m=$ ote & Vata \\
\hline Engkau & makan & nasi & minum & air & bawa & Jagung \\
\hline
\end{tabular}

Proclitic also cross-reference the second singular pronoun moe 'you' in the sentence Moe $g=o$ kluo 'You eat rice', Moe $m=e n u$ vai 'You drink water', and Moe $m=$ otE vata 'You bring corn'. There is a phonological change in the morphological form of $g=o$ 'eat', $m=e n u$ 'to drink' and m=ete 'bring'. The second singular pronoun is crossreferenced proclitically with $g=, m=$ and $m=$. Interestingly, the sound $/ \mathrm{m} /$ in moe is replaced by the sound $/ \mathrm{g} /$ and the sound $/ \mathrm{a} /$ changes to $/ \mathrm{o} /$ in the verb $g=o$. The sounds $/ \mathrm{m} /$ and $/ \mathrm{g} /$ are two sounds that are different in place and articulator but are both consonantal and voiced sounds. The replacement of the sound $/ \mathrm{a} /$ with $/ \mathrm{o} /$ is based on the predominance of the sound $/ \mathrm{o} /$ in the second singular pronoun moe 'you' over the sound $/ \mathrm{a} /$ in the precategorial verb $=a$ 'to eat'. These two vowel sounds differ both in the backness and height of the tongue but are the same roundness. The /a/ sound is a low central sound, the /o/ sound is a mid and back sound but both are round sounds. The proclitic $m=$ in the precategorial verb $m=e n u$ 'you drink', $m=e t e$ 'you carry' is a reference to $m=$ in the second singular pronoun moe.

\begin{tabular}{l} 
Examples (3) \\
\begin{tabular}{|l|l|l|l|l|l|l|}
\hline Nae & $g=e$ & kluo & $n=e n u$ & vai & $n=$ ete & vata \\
\hline Nae & $g=\ddot{z}$ & kluo & $n=e n u$ & vai & $n=$ ote & vata \\
\hline Dia & Makan & nasi & minum & air & Bawa & jagung \\
\hline
\end{tabular} \\
'Dia makan nasi', 'Dia minum air', 'Dia bawa jagung' \\
'S(H)e ate rice', S(H)e drank water', 'S(H)e brought corn' \\
\hline
\end{tabular}

Example (3) shows that the morphophonological process occurs in the precategoria 1 verb $g=\ddot{\partial}$. The precategorial verb $=a$ 'eat' cross-refererences a third person singular pronominal with the clitic $g=$. This means that the proclitic $g=$ and the third singular pronoun differ phonologically. Articulatorily the sound $/ \mathrm{g} /$ is a dorsovelar sound and the sound $/ \mathrm{m} / \mathrm{is}$ a bilabial sound. Even so, they share some of the same features, namely that they are both consonantal and voiced. Therefore, the addition of this sound has a phonological origin. The change of the sound /a/ in the precategorial verb $=a$ to /ä/ is a phonological event in its morphological expression. The /a/ and /ä/ sounds differ in height and roundness but are the 
same in backness, as both are central vowels. The precategorial verbs $n=e n u$ 'He drank' and $n=$ ate 'he brought' refer to the third singular pronominal cross with clitic $n=$. There are no morphophonological changes in these two precategorial verbs.

Example (4)

\begin{tabular}{|c|c|c|c|c|c|c|}
\hline Tite & $t=e k e$ & kluo & $t=e n u$ & $v a i$ & $t=$ ete & vata \\
\hline Tite & $t=\partial k \partial$ & kluo & $t=e n u$ & vai & $t=\partial t E$ & vata \\
\hline Kita & makan & nasi & minum & air & bawa & jagung \\
\hline
\end{tabular}

The precategorial verb $t=\partial t o$ 'we eat' is a verb derived from the precategorial verb $=a$. Attaching the first plural inclusive proclitic form $t=$, gives the form $t=\partial k \partial$ instead of $t=a$. This quite significant change states that there is an insertion of the sound /ə/assuming that the precategorial verb is $=k a$. If so then there is an insertion of a /ə/ sound as a speech release sound. The precategorial verbs $=e n u$ 'to drink', and =ate 'carry' refer to the first plural inclusive pronoun with proclitic $t=$ unchanged.

Example (5)

\begin{tabular}{|c|c|c|c|c|c|c|}
\hline Kame & $m=e k e$ & kluo & $m=e n u$ & vai & $m=$ ete & vata \\
\hline Kame & $m=\partial k \partial$ & kluo & $m=e n u$ & vai & $m=\partial t E$ & vata \\
\hline Kami & makan & nasi & minum & air & Bawa & jagung \\
\hline \multicolumn{7}{|c|}{ 'Kami makan nasi', 'Kami minum air', 'Kami bawa jagung' } \\
\hline
\end{tabular}

The precategorial verbs $=e n u$ 'to drink' and =ate 'carry' refes to the first plural pronoun exclusive with $m=$. There are no phonological and morphological changes but only syntactic changes. This means that the addition of clitics to the precategorial form causes the precategorial verb to fulfill out the syntactic function of a verb predicate semantically. In contrast to the two precategorial verbs already described, the precategorial verb $=a$ 'eat' is cross-referenced with the proclitic $m=$ accompanied by morphophonological changes. The sound $/ \mathrm{k} /$ in kame and the sound $/ \mathrm{m} /$ in moka 'eat' are two different sounds with respect to manner and articulator, but share a distinctive feature, namely that they are both consonantal. There is an insertion of sound assuming that the pre-historic form is $=k a$. If so, then there is a sound /a/ which is inserted to ease speech. In addition, there is an effect of the bilabial sound $/ \mathrm{m} /$ in the first plural exclusive of kame.

Example (6)

\begin{tabular}{|c|c|c|c|c|c|c|}
\hline Mio & $g=e$ & kluo & $m=e n u$ & $v a i$ & $m=e t e$ & vata \\
\hline Mio & $g=\ddot{e}$ & kluo & $m=e n u$ & $v a i$ & $m=\partial t E$ & vata \\
\hline Kamu & makan & nasi & minum & air & bawa & jagung \\
\hline
\end{tabular}

The precategorial verb $=e n u$ 'to drink' and =ate 'carry' refers to the cross-reference of the second plural pronoun with the proclitic $m=$ according to the first sound of mio 'you (pl)'. This juxtaposition causes neither phonological nor morphological changes. The precategorial verb $=a$ 'eat' cross-references the second plural pronoun with the proclitic $g=$. The sound $/ \mathrm{m} /$ in moe 'you' and the sound $/ \mathrm{g} /$ in $g \ddot{e}$ are two different sounds with respect to manner and articulator but these two sounds are both consonantal and voiced. So the inserted sounds have phonological reasons. In addition, there is a sound change in the precategorial verb $=a$ 'eat' to a /ë/ sound. These two sounds are different in backness, roundness and height but share distinctive features, namely that they are both syllabic 
and sonorant. In plain view, they are different but phonologically they both have the same characteristics.

\section{Example (7)}

\begin{tabular}{|c|c|c|c|c|c|c|}
\hline rae & $r=e k e$ & kluo & $r=e n u$ & vai & $r=e t e$ & vata \\
\hline rae & $r=\partial k \partial$ & kluo & $r=e n u$ & vai & $r=\partial t E$ & vata \\
\hline Mereka & makan & nasi & minum & air & bawa & jagung \\
\hline \multicolumn{7}{|c|}{ 'Mereka makan nasi', 'Mereka minum air', 'Mereka bawa jagung' } \\
\hline
\end{tabular}

The precategorial verbs $r=\partial k \partial$, 'they eat', $r=\partial n u$ 'they drink', and $r=\partial t e$ 'they carry' crossreference the third plural pronoun with the proclitic $r=$. The precategorial verb $=a$ 'eat' crossreferences the third plural pronoun with the proclitic $r=$ by inserting the sound / $/ /$ as a speech connector. This is based on the assumption that the precategorial verb form 'to eat' is $=k a$.

The precategorial form of 'eating' $=a$ changes due to the environment it follows, especially the primary environment, both singular and plural. The data analysis shows that the singular pronouns $(1,2,3)$ and plural (2) take the precategorial form $=a$ and the plural pronouns (1 and 3) take the form $=k a$. If so, then the sound $/ \partial /$ in the precategorial verbs $t=\partial k \partial$, 'We eat', $m=\partial k \partial$, 'We eat' and $r=\partial k \partial$ 'They eat' is verbal. The sound / / / is used to smooth speech because the sound /ə/ is the most dominant sound in the plural pronouns 1 and 3. The morphophonological process in Example 1-7 does not change the word class or word category.

\section{Replacement (insertion) of Initial Sounds and Changes of Intransitive Precategorial Verb Sounds}

Inflectional marking does not only occur in transitive pretegorial verbs but also in intransitive precategorial verbs as can be seen in the following example (8).

Example (8).

\begin{tabular}{|l|l|l|l|l|}
\hline Goe,moe,nae,tite,kame,mio, rae & $k=a i, m=a i, n=a i, t=a i, m=a i, m=a i, r=a i$ & vule & nepen & nuleng \\
\hline Goe,moe,nae,tite, kame,mio, rae & $k=a i, m=a i, n=a i, t=a i, m=a i, m=a i, r=a i$ & vula & nepen & nulang \\
\hline $\begin{array}{l}\text { Saya,engkau,dia,kita,kami,kam } \\
\text { u,mereka }\end{array}$ & $\begin{array}{l}\text { Saya=pergi,engkau=pergi,dia=pergi,kita } \\
\text { =pergi, kami=pergi, kamu=pergi, } \\
\text { mereka=pergi }\end{array}$ & pasar tadi & pagi \\
\hline 'Saya, engkau, dia, kita, kami, kamu, mereka pergi ke pasar tadi pagi' \\
\hline 'They went to the market this morning'
\end{tabular}

The precategorial verb $=a i$ 'to go' proclitically cross-references to a pronoun, either singular or plural. Phonological changes occur in the morphological form $k=a i$ 'I go'. The $/ \mathrm{g} /$ goe sound is replaced by the sound $/ \mathrm{k} /$ in $k=a i$ because phonologically these two sounds are both dorsovelar. What distinguishes it is that the sound $/ \mathrm{g} /$ is voiced, while the sound $/ \mathrm{k} /$ is voiceless. It can be understood that the morphophonological changes in the precategorial verb $=a i$ 'go' are based on the similarity of the phonological features of the two sounds. Other pronouns are cross-referenced by taking the first sound. Sound substitution can also be observed in some intransitive precategorial verbs in Table 1 below.

Table 1. Addition and Replacement of Intransitive Prakategorial Verb Sounds

\begin{tabular}{|l|l|l|l|l|l|l|l|l|}
\hline Gloss/Pronomina & goe & moe & nae & tite & kame & mio & rae \\
\hline$=i \ddot{a}$ & inap & $k=i \ddot{a}$ & $m=i \ddot{a}$ & $n=i \ddot{\partial}$ & $t=i \ddot{a}$ & $m=i \ddot{a}$ & $m=i \ddot{a}$ & $r=i \ddot{a}$ \\
\hline$=a b e$ & harus & $k=a b e$ & $m=a b e$ & $n=a b e$ & $t=a b e$ & $m=a b e$ & $m=a b e$ & $r=a b e$ \\
\hline$=$ ode & boleh & $k=$ ode & $m=$ ode & $n=$ ode & $t=$ ode & m=ode & m=ode & $r=$ ode \\
\hline
\end{tabular}


The morphophonological process occurs in the first singular pronoun, the sound $/ \mathrm{g} /$ is replaced by the $/ \mathrm{k} /$ sound. This morphophonological change is systemic and does not change the word class or word category.

\section{Replacement (insertion) of Initial Sounds and Change of Basic Verb Sounds Replacement (insertion) of Initial Sounds and Transitive Basic Verb Sound Changes}

The precategorial verb cannot be independent phonologically, morphologically and syntactically. This lack of independence causes the precategorial verb to cross-refer to the pronoun that it follows so that it becomes a complete linguistic unit phonologically, morphologically and syntactically. In contrast to precategorial verbs, basic verbs can crossrefer to the pronouns that they follow in an enclitic way. This means that the precategorial verb cross-refers to the pronoun which it follows proclitically. The addition of the sound at the end of the root verb is also very interesting to study because of its uniqueness. In the following, we will discuss the addition of sounds to transitive basic verbs in LDLL.

\section{Example (9)}

\begin{tabular}{|l|l|l|l|l|l|}
\hline a. & Goe & akal & nae/rae & nepen & nuleng \\
\hline & Goe & akal & nae/rae & nepen & nulang \\
\hline & Saya & tipu & dia/mereka & tadi & pagi \\
\hline & 'Saya membohongi dia/mereka tadi pagi' \\
\hline & 'I lied to him/them this morning' \\
\hline \hline b. & Goe & akal & nae/rae & nepen & lero \\
\hline & Goe & akal & nae/rae & nepen & laro \\
\hline \multicolumn{7}{|l|}{ Saya tipu } & dia/mereka & tadi & siang \\
\hline \multicolumn{7}{|c|}{ 'Saya membohongi dia tadi siang' } \\
\hline
\end{tabular}

The basic verb "lie" is a bivalent verb with two arguments, one argument as the subject and one argument as an object. The nae 'dia' and rae 'them' objects in this sentence can be dropped and replaced with the affix $=o,=v e$. These clitics are attached to the end of the root verb. Even though they are attached to basic verbs, they do not change the class of words at all.

\begin{tabular}{l} 
Example (10) \\
\begin{tabular}{|l|l|l|l|l|l|}
\hline a. & Kame & peso & nae/rae & veli & vule \\
\hline & Kame & paso & nae/rae & vali & vula \\
\hline & Kami & lepas & dia/mereka & di.sana & pasar \\
\hline & 'Kami melepaskan dia/mereka di pasar' \\
\hline & 'We leave him/her in the market' \\
\hline b. & Kame & peso=lo, $=$ ve & veli & vule \\
\hline & Kame & paso=lo, $=v e$ & vali & vula \\
\hline & Kami & lepas & dia/mereka & di.sana & pasar \\
\hline & 'Kami melepaskan nya/mereka di pasar' \\
\hline
\end{tabular} \\
'We leave him/her in the market' \\
\hline
\end{tabular}

The basic verb predicate in in sentence (10) is paso 'to leave' ending with a vowel /o/. The third singular pronouns' enclitic form is $=o$. If this enclitic were attached to the root verb paso 'release' it would become pesoo, with gemination of the sound /o/. This form is unacceptable and is never found in the LDLL lexicon. In order to pronounce it correctly, the sound /l/ will be added to this basic verb. The addition of the sound /1/ acts semantically as 
an intensifier. Besides indicating intensity, the sound /1/ functions as to ease speech. Thus, there is no sound lengthening or gemination of $/ \mathrm{o} /$. What's interesting is why it must be an $/ 1 /$ sound and not some other sound. The insertion or addition of the sound $/ 1 /$ is due to the influence of the fricative /s/ sound. The /1/ and /s/ sounds are two sounds that have different points of articulation but use the same articulator. In addition, these two sounds are also consonantal, coronal, anterior and voiceless. The similarity of these characteristics causes the presence of $/ 1 /$ as a facilitator of speech. The addition of the sound /1/ does not change the word class. Enclitic $=v e$ is the third clitic plural pronoun whose appearance is most constant without any changes in either the addition or insertion of sounds.

Example (11)

\begin{tabular}{|l|l|l|l|l|}
\hline a. & Muku & eka & nae /rae & we \\
\hline & Muku & əka & & we \\
\hline & Tolong & turun & $=$ dia, =mereka & art. \\
\hline & 'Tolong turunkan barang-barangnya dia/mereka' \\
\hline & 'Please, unload him/them' & we \\
\hline b. & Muku & eka=ko, =ve & we \\
\hline & Muku & aka=ko, =ve & art. \\
\hline & Tolong & turun=dia, =mereka & \\
\hline & 'Tolong turunkan barang-baranya dia/mereka' \\
\hline & 'Please, unload him/them' \\
\hline
\end{tabular}

The objected nae 'him' and rae 'they' in example (11) can be expressed by clitics $=o$ and $=v e$. The clitic $=v e$ 'they' does not undergo phonological changes while the clitic $=o$ does undergo changes. The sound $/ \mathrm{k} /$ between the sound $/ \mathrm{a} /$ and clitic $=o$ occurs due to the dominance of the sound or the effect of the sound $/ \mathrm{k} /$ on the root verb $2 k a$ 'to bring down'. The sound $/ \mathrm{k} /$ becomes the smoothest sound $/ \mathrm{a} /$ and the enclitic $=o$. The addition of these two affixes to the root verb $ə k a$ 'to bring down' does not change the word class. The mutual influence of sound or the dominance of sound also occurs in the following examples.

Example (12)

\begin{tabular}{|l|l|l|l|l|}
\hline a. & Goe & tepak & nae /rae & mu rua \\
\hline & Goe & topak & nae /rae & mu rua \\
\hline & Saya & tempeleng & $=$ dia, =mereka & tambah dua \\
\hline & 'Saya menempeleng dia/mereka dua kali' \\
\hline & \multicolumn{3}{l}{ 'I salpped him/his twice' }
\end{tabular}

\begin{tabular}{|l|l|l|l|}
\hline b. & Goe & tepak=o/=ve & mu rua \\
\hline & Goe & trpak=o/=ve & mu rua \\
\hline & Saya & tempeleng=dia/=mereka & tambah dua \\
\hline & 'Saya menempelengnya /mereka dua kali' \\
\hline & 'I slapped him/his twice'
\end{tabular}

The basic verb trpak 'tempeleng' ends with a $/ \mathrm{k} /$ sound so that the addition of the third singular and plural pronouns' enclitics does not cause any phonological changes. The basic verbs ending with the sound $/ \mathrm{k} /$ which get added enclitic $=o$ 'him' and $=v e$ 'they' can also be seen in Table 2 below.

Table 2. Basic Verb Ends Sounds / $\mathrm{k} /$

\begin{tabular}{|c|c|c|c|c|c|c|c|c|c|}
\hline \multicolumn{2}{|c|}{ Glos/Pronomina } & goe & moe & nae & tite & kame & mio & rae & English \\
\hline lempar & hetək & hetak & hetək & $h e t \partial k=o$ & hetzk & hetək & hetak & hetək $=v e$ & to throw \\
\hline tangkap & apak & apək & apak & apək=o & әрәk & apək & apak & apak $=v e$ & athch \\
\hline urut & huak & huak & huak & huak=o & huak & huak & hua & huak-v(e) & to massage \\
\hline
\end{tabular}


Table 2 data depicts a systematic change in the enclitics of the third singular and plural pronouns.

Example (13)

\begin{tabular}{|l|l|l|l|l|}
\hline a. & Moe & tao & nae /rae & ike rua \\
\hline & Moe & tao & nae /rae & ikə rua \\
\hline & Engkau & simpan & $=$ dia, =mereka & ikan dua \\
\hline & 'Engkau menyimpan dia/mereka ikan dua ekor' \\
\hline & 'You kept him/her/them two fish' \\
\hline b. & Moe & tao=ro/=ve & ike rua \\
\hline & Moe & tao=ro/=ve & ikə rua \\
\hline & Engkau & simpan=dia/ =mereka & ikan dua \\
\hline & 'Engkau menyimpannya/mereka ikan dua ekor' \\
\hline & 'You kept him/her/them two fish' \\
\hline
\end{tabular}

The transitive root predicate tao 'store' in example (13) gets the enclitic =ro added, as $t a u=r o$ 'store him' and tao=ve 'store them'. The addition of the enclitic pronoun to the third singular causes a phonological process. The insertion of the sound $/ \mathrm{r} /$ becomes a smoothing sound in the pronunciation of the basic unit. If there is no insertion of the sound $/ \mathrm{r} /$, then the unit becomes a non-morphological and semantic unit. The unique thing is, why should the sound be $/ \mathrm{r} /$ ? Phonologically, the sound $/ \mathrm{r} /$ is the sound of choice for the speech facilitator because the sound $/ \mathrm{r} /$ has the same characteristics as the sound $/ \mathrm{t} / \mathrm{in}$ basic verbs. These two sounds are articulated different but share a place of articulation, namely apicoalveolar. In addition, the two sounds / $/$ / and $/ \mathrm{r} /$ have the same distinctive characteristics, namely, they are both consonantal, sonorant, anterior and coronal. Another morphophonological symptom is a change in the sound /o/ of the basic verb tao 'save' to $/ \mathrm{u} /$. These two sounds have the same characteristic, namely the sound is round and back but the difference is that the sound $/ \mathrm{o} /$ is a mid sound, the sound $/ \mathrm{u} /$ is a high sound. The sound $/ \mathrm{o} /$ is raised due to the effect of the inserted sound $/ \mathrm{r} /$. The sound $/ \mathrm{r} /$ functions as an intensifier and speech facilitator. The insertion of the sound $/ \mathrm{r} /$ in the third singular pronouns is also found in a number of transitive root verbs as shown in Table 3 below.

Table 3. Sound Insertion / $r$ In A Number of Transitive Base Verbs

\begin{tabular}{|c|c|c|c|c|c|c|c|c|}
\hline Glos/Pronomina & goe & moe & nae & tite & kame & mio & rae & English \\
\hline dorong & bogo & bogo & bogo=ro & bogo & bogo & bogo & bogo=ve & push \\
\hline potong & poro & poro & poro $=\boldsymbol{r o}$ & poro & poro & poro & poro=ve & cut \\
\hline bangun & baku & baku & baku=ro & baku & baku & baku & baku=ve & get up \\
\hline (beri) makan & pau & pau & pau=ro & pau & pau & pau & pau=ve & eat \\
\hline gendong & bote & bote & boti=ro & boti & boti & boti & boti=ve & carry \\
\hline terima & hode & hode & hodi=ro & hode & hode & hode & hode=ve & receive \\
\hline masak & denə & denə & dena=ro & denə & denə & denə & dena=ve & cook \\
\hline pancing & veda & veda & veda=ro & veda & veda & veda & veda=ve & fish \\
\hline berita(kan) & gəpa & gəpa & gəpa=ro & gəpa & gəpa & gəpa & gəpa=ve & tell \\
\hline sisir & giri & giri & giri=ro & giri & giri & giri & giri=ve & comb \\
\hline beli & hope & hope & hope=ro & hope & hope & hope & hope=ve & buy \\
\hline
\end{tabular}

Table 3 illustrates that transitive root verbs ending in the vowel sound / o, u, e, a, I / get the insertion sound $/ \mathrm{r} /$. The insertion of the sound $/ \mathrm{r} /$ functions as an intensifier and emitter. The addition of the enclitics =ro and =ve does not change the word category. 


\section{Replacement (insertion) of Initial Sounds and Changes of Basic Intransitive Verb Sounds}

The basic intransitive verb also cross-references the pronoun which it follows by an affix. The pronoun clitics are attached at the end of the intransitive root verb. The addition of clitics at the end of intransitive root verbs also causes a phonological change. The following will describe the addition of clitics at the end of intransitive root verbs that show morphophonological phenomena.

\section{Example (14)}

\begin{tabular}{|l|l|l|}
\hline $\begin{array}{l}\text { Goe,moe, nae, tite, kame, mio, } \\
\text { rae }\end{array}$ & $\begin{array}{l}\text { hebo=ke, hebo=ko,hebo=va, hebo=te, hebo=kem, } \\
\text { hebo=kre, hebo=ri }\end{array}$ & di pi \\
\hline $\begin{array}{l}\text { Goe,moe, nae, tite, kame, mio, } \\
\text { rae }\end{array}$ & $\begin{array}{l}\text { habo=ka, həbo=ko,həbo=va, habo=te, həbo=kam, } \\
\text { həbo=kre, habo=ri }\end{array}$ & di pi \\
\hline $\begin{array}{l}\text { Saya, engkau, dia, kita, kami, } \\
\text { kamu, mereka }\end{array}$ & $\begin{array}{l}\text { mandi=saya, mandi=engkau, mandi=dia, di sini } \\
\text { mandi=kita, mandi=kami, mandi=kamu, } \\
\text { mandi=mereka }\end{array}$ & \\
\hline 'Saya, engkau, dia, kita, kami, kamu, mereka mandi di sini' \\
\hline 'I,you, he, she, we, you, they bathe here'
\end{tabular}

Example (14) states that the predicate of an intransitive root verb cross-references both singular and plural pronouns in an enclitic manner. These attached clitics show changes which can be explained phonologically. The first singular pronouns are pronunced with the sound $/ \mathrm{k} /$. The sounds $/ \mathrm{g} /$ and $/ \mathrm{k} /$ are somewhat different but articulatorily similar. This means that the sounds $/ \mathrm{g} /$ and $/ \mathrm{k} /$ have the same characteristics so that phonologically these two sounds can replace each other. The second singular pronoun moe 'you' has an enclitic $=k o$. There is an insertion of the sound $/ \mathrm{k} /$ between the last sounds of the second singular $/ \mathrm{o} /$ and the enclitic pronoun $=o$. The sound $/ \mathrm{k} /$ is different from the sound $/ \mathrm{m} /$. Even so, the sound $/ \mathrm{k} /$ is used as a speech release sound $h a b o=k o$. The insertion of the sound $/ \mathrm{k} /$ also occurs in the second plural pronoun. This means that the insertion of the sound $/ \mathrm{k} /$ in the two plural pronouns also acts as a speech facilitator. The enclitic singular third pronoun is $=v a$. Phonologically, the sounds $/ \mathrm{n} /$ and $/ \mathrm{v} /$ are two different sounds that are articulated differently but share distinctive features, namely that they are both consonantal and anterior. The insertion of the $/ \mathrm{v} /$ sound is for smoothing speech. The first plural pronouns (inclusive and exclusive) and the third plural enclitics refer to the first sound of each pronoun. This means that there is no phonological change in the enclitization. The consistency of changes in the enclitization of each intransitive root verb can be seen in Table 4 below.

Table 4. Consistency of Intransitive Basic Verb Acclimatization

\begin{tabular}{|c|c|c|c|c|c|c|c|c|c|}
\hline \multirow{2}{*}{\multicolumn{2}{|c|}{ Gloss/Pronomina }} & goe & moe & nae & tite & kame & \multirow{2}{*}{$\begin{array}{l}\text { mio } \\
\text { you }\end{array}$} & \multirow{2}{*}{$\begin{array}{l}\text { rae } \\
\text { they }\end{array}$} & \multirow[t]{2}{*}{ english } \\
\hline & & $I$ & you & $s(h) e$ & \multicolumn{2}{|c|}{ we } & & & \\
\hline naik & gere & $=k \partial$ & $=k o$ & $=v a$ & $=t e$ & $=k \partial m$ & $=k r e$ & $=r i$ & come here \\
\hline mandi & hebo & $=k \partial$ & $=k o$ & $=v a$ & $=t e$ & $=k \partial m$ & $=k r e$ & $=r i$ & take a bath \\
\hline dayung & bai & $=k \partial$ & $=k o$ & $=\phi$ & $=t e$ & $=k \partial m$ & $=r e$ & $=i r i$ & row \\
\hline kuap & pmoav & $=k \partial$ & $=O$ & $=a$ & $=t e$ & $=k \partial m$ & $=r e$ & $=i$ & evaporate \\
\hline bangun & hogo & $=k \partial$ & $=k o$ & $=r a$ & $=t e$ & $=k \partial m$ & $=k r e$ & $=r i$ & get up \\
\hline lari & plae & $=k \partial$ & $=k o$ & $=v a$ & $=t e$ & $=k \partial m$ & $=k r e$ & $=r i$ & run \\
\hline
\end{tabular}

Phonological changes occur in the intransitive root verbs bai 'paddle', pmoav 'to yawn' and hogo 'to wake up'. There is a zero affix in the intransitive root verb bai 'paddle', the third singular pronoun. If the third singular enclitic pronouns were attached, the morphological form would become $b a i=o$, and if the sound $/ \mathrm{k} /$ were inserted, it would become $b a i=k o$. This 
form is completely absent in the lexicon of the Lamalera dialect. Although it did not undergo morphological changes, there were changes suprasegmentally and semantically.

Phonological changes occur in the intransitive root verb pmoav 'to yawn' for the enclitic singular third pronoun. There is no insertion of any sound because the last sound of this basic verb is the sound $/ \mathrm{v} /$. This sound is so dominant that it does not allow the insertion of sound to occur. This also occurs in plural pronouns $(1,2,3)$.

Sound changes also occur in the enclitic pronoun of the third singular intransitive root verb hogo 'wake'. There is insertion of the sound $/ \mathrm{r} /$ and not $/ \mathrm{k} /$. Phonologically the sound $/ \mathrm{n} /$ in nae 'dia' and sound $/ \mathrm{r} /$ in the enclitic $=r a$ are two sounds that are articulatorily different but share a distinctive feature, that they are both apicoalveolar. Thus, it can be understood that these two sounds in certain circumstances or in a certain environment can both replace each other.

\section{Example (15)}

\begin{tabular}{|l|l|l|}
\hline Goe,moe, nae, tite, kame, mio, rae & $\begin{array}{l}\text { dei=ngke, dei=ngo, dei=nga, dei=ngte, dei=ngkem, } \\
\text { dei=ngre,dei=ngri }\end{array}$ & di pi \\
\hline Goe,moe, nae, tite, kame, mio, rae & $\begin{array}{l}\text { dei=ngka, dei=ngo, dei=nga, dei=ngte, dei=ngkam, } \\
\text { dei=ngre, dei=ngi }\end{array}$ & di pi \\
\hline $\begin{array}{l}\text { Saya, engkau, dia, kita, kami, kamu, } \\
\text { mereka }\end{array}$ & $\begin{array}{l}\text { berdiri=saya, berdiri=engkau, berdiri=dia, berdiri=kita, } \\
\text { berdiri=kami, berdiri=kamu, berdiri=mereka }\end{array}$ & $\begin{array}{l}\text { di } \\
\text { sini }\end{array}$ \\
\hline 'Saya, engkau, dia, kita, kami, kamu, mereka berdiri di sini' \\
\hline 'I, You, He, She, We, You, They stand here' \\
\hline
\end{tabular}

The example (15) shows that there is insertion of thesound /ng/ in all enclitic forms, both singular and plural. Phonologically it can be explained why the sound $/ \mathrm{ng} /$ is inserted and not other sounds. There are similarities in phonological features between the first sound of the singular pronouns /g/ and the sound /ng/ (consonantal, velar, back, voiced), there are similarities in phonological features between the first sound of the second singular and plural pronouns $/ \mathrm{m} /$ with $/ \mathrm{ng} /$ (consonantal, voiced), there are similarities in phonological features between the first sound of the third singular pronouns /n/ with /ng/ (consonantal, voiced, nasal), and there are similarities in phonological features between the sound of the first exclusive plural pronouns $/ \mathrm{k} /$ and $/ \mathrm{ng}$ / (consonantal, voiced, nasal), and there are similarities in phonological features between the first plural inclusive sound $/ \mathrm{t} / \mathrm{and}$ the third plural pronoun $/ \mathrm{r} /$ with the inserted sound $/ \mathrm{ng} /$. These three sounds $/ \mathrm{t} / / \mathrm{r} /, / \mathrm{ng} /$ have the same characteristics, namely that they are consonantal and sonorant. The insertion of the sound $/ \mathrm{ng} /$ in all of these pronounced forms serves as an intensifier and a smoothener for speech. The insertion of this /ng/ sound can be observed in table 5 below.

Table 5. Insertion Consistency of Sound /ng/ on Intransitive Basic Verbs

\begin{tabular}{|l|l|l|l|c|c|c|c|c|l|}
\hline Gloss & DL & goe & moe & nae & tite & kame & mio & rae & \\
\hline apung & bao & $=n g k \partial$ & $=n g o$ & $=n g a$ & $=n g t e$ & $=n g k \partial m$ & $=n g r e$ & $=n g i$ & float \\
\hline suara(ber-) & ala & $=n g k \partial$ & $=n g o$ & $=n g a$ & $=n g t e$ & $=n g k \partial m$ & $=n g r e$ & $=n g i$ & make a noise \\
\hline selam & hala & $=n g k \partial$ & $=n g o$ & $=n g a$ & $=n g t e$ & $=n g k \partial m$ & $=n g r e$ & $=n g i$ & dive \\
\hline terjun & sole & $=n g k \partial$ & $=n g o$ & $=n g a$ & $=n g t e$ & $=n g k \partial m$ & $=n g r e$ & $=n g i$ & plunge \\
\hline
\end{tabular}

\section{Example (16)}

\begin{tabular}{|l|l|l|}
\hline $\begin{array}{l}\text { Goe,moe, nae, tite, kame, } \\
\text { mio, rae }\end{array}$ & $\begin{array}{l}\text { tobo=lke, tobo=o, tobo=la, tobo=lte, tobo=lkem, } \\
\text { tobo=lre, tobo }=l i\end{array}$ & di pi \\
\hline $\begin{array}{l}\text { Goe,moe, nae, tite, kame, } \\
\text { mio, rae }\end{array}$ & $\begin{array}{l}\text { tobo=lka, tobo=lo, tobo=la, tobo=lte, tobo=lkam, } \\
\text { tobo=lre, tobo=li }\end{array}$ & di pi \\
\hline
\end{tabular}


Saya, engkau, dia, kita, duduk=saya, duduk=engkau, duduk=dia, duduk=kita, di sini kami, kamu, mereka duduk=kami, duduk=kamu, duduk=mereka

'Saya, engkau, dia, kita, kami, kamu, mereka duduk di sini'

'I, You, He, She, We, You, They sit here'

Example (16) indicates lateralization. All the sounds of the first pronouns, whether singular goe, moe, nae or plural tite, kame, mio, rae are referred to as lateral sounds. There is insertion of a sound /l/ which phonologically does not have the same characteristics and only functions as an intensifier and facilitator of speech. The insertion of the sound /1/ can also be observed in the following example (17).

\section{Example (17)}

\begin{tabular}{|l|l|l|}
\hline $\begin{array}{l}\text { Goe,moe, nae, tite, kame, } \\
\text { mio, rae }\end{array}$ & $\begin{array}{l}\text { beso=lke, beso=lo, beso=la, beso=lte, beso=lkem, } \\
\text { beso=lre, beso=li }\end{array}$ & di pi \\
\hline $\begin{array}{l}\text { Goe,moe, nae, tite, kame, } \\
\text { mio, rae }\end{array}$ & $\begin{array}{l}\text { baso=lka, boso=lo, baso=la, bəso=lte, bəso=lkam, } \\
\text { baso=lre, bəso=li }\end{array}$ & di pi \\
\hline $\begin{array}{l}\text { Saya, engkau, dia, kita, } \\
\text { kami, kamu, mereka }\end{array}$ & $\begin{array}{l}\text { datang=saya, =engkau, =dia, =kita, =kami, =kamu, } \\
\text { =mereka }\end{array}$ & di sini \\
\hline 'Saya, engkau, dia, kita, kami, kamu, mereka datang di sini' \\
\hline 'I, You, He, She, We, You, They came here'
\end{tabular}

\section{Example (18)}

Goe,moe, nae, tite, kame, lua=tke, lua=to, lua=ta, lua=te, lua=tkem, lua=tre, kae mio, rae lua $a=t i$

Goe,moe, nae, tite, kame, lua=tkə, lua=to, lua=ta, lua=te, lua=tkəm, lua=tre, kae mio, rae lua $=t i$

Saya, engkau, dia, kita, datang=saya, =engkau, =dia, =kita, =kami, =kamu, sudah kami, kamu, mereka $\quad=$ mereka

'Saya, engkau, dia, kita, kami, kamu, mereka sudah turun'

'I, You, He, She, We, You, They am/is/are down'

The example (18) illustrates that all pronouns, both singular and plural, havethe sound /t/. The sound / $t /$ is a voiceless apicoalveolar stop and it affects all the first sounds of the pronouns goe, moe, nae, tite, kame, mio, rae, because of their similarity as consonantal sounds. It is this similarity in consonantal characteristics that causes the sound / $t /$ to be very dominant in all enclitic forms.

\section{Example (19)}

\begin{tabular}{|l|l|l|}
\hline Goe, moe, nae, tite, kame, mio, rae & $\begin{array}{l}\text { turu=ke, turu=ko, turu=va, turu=te, turu=kem, } \\
\text { turu=kre, turu=vi }\end{array}$ & kae \\
\hline Goe,moe, nae, tite, kame, mio, rae & $\begin{array}{l}\text { turu=ko, turu=ko, turu=va, turu=te, turu=kam, } \\
\text { turu =kre, turu=vi }\end{array}$ & kae \\
\hline $\begin{array}{l}\text { Saya, engkau, dia, kita, kami, } \\
\text { kamu, mereka }\end{array}$ & $\begin{array}{l}\text { datang=saya, =engkau, =dia, =kita, =kami, =kamu, sudah } \\
=\text { mereka }\end{array}$ & sald \\
\hline 'Saya, engkau, dia, kita, kami, kamu, mereka sudah tidur' & \\
\hline I, you, he, she, we, you, thet had slept'
\end{tabular}

The intransitive root verb 'sleep' cross-references all pronouns with varying enclitics. The insertion of the sound $/ \mathrm{k} /$ in all pronoun clitics is based on the similarity of phonological features, the similarity of the first sound of the pronoun referred to and the function of insertion of the sound. The insertion of the sound $/ \mathrm{k} /$ in the verb predicate $t u r u=k a$, the first singular pronoun, turu $=$ the second singular $k o$ pronoun, turu=kam the first plural exclusive pronoun and turu=kre the second plural pronoun is because of the distinctive 
feature similarity to the sound /g/ goe 'I', /m/ moe 'you', /k/ kame 'we', /m/ mio 'you'. The insertion of the sound $/ \mathrm{v} /$ in the third singular and plural pronouns is also based on the similarity of the distinctive features: $/ \mathrm{n} /$ in nae and $/ \mathrm{v} /$ share distinctive features and are both consonantal and anterior. Likewise, the sounds $/ \mathrm{r} / \mathrm{rae}$ and $/ \mathrm{v} /$ are both consonantal, anterior and voiced sounds. It is not surprising that the $/ \mathrm{v} /$ sound is used as a speech facilitating sound. The insertion of the sound $/ \mathrm{v} /$ can also be noticed in a number of intransitive root verbs in table 6 below.

Table 6. Insertion of Sound $/ \mathrm{v} /$ in Intransitive Basic Verbs

\begin{tabular}{|l|l|l|l|l|l|l|l|l|l|}
\hline \multicolumn{2}{|l|}{ Gloss/Pronomina } & goe & moe & nae & tite & kame & mio & rae & \\
\hline berjalan & pana & $=v k \partial$ & $=v o$ & $=v a$ & $=v t e$ & $=v k a m$ & $=v r e$ & $=r i$ & walk \\
\hline berkarang & pnima & $=v k \partial$ & $=v o$ & $=v a$ & $=t e$ & $=k \partial m$ & $=k r e$ & $=r i$ & fihsing \\
\hline berjaga & tia & $=v k \partial$ & $=v o$ & $=v a$ & $=v t e$ & $=v k a m$ & $=v r e$ & $=v i$ & stay up late \\
\hline
\end{tabular}

\section{CONCLUSION}

The inflectional markers in LDLL are clitics. LDLL inflectional clitics act as crossreferencers on the verb predicate. The verb predicate will clitically cross-refer to the pronoun which serves as the clause subject. Clitics that are used for cross-reference on verbal predicates are categorized as proclitics and enclitics. Proclitics are clitics that attach to the beginning of the precategorial verbs, both transitive and intransitive. Precategorial verbs are incomplete verbs phonologically, morphologically, semantically and syntactically. This means that phonologically, the verb does not have a complete sound, morphologically it is not yet independent as a word, semantically the verb has no meaning and syntactically the verb does not yet carry out the syntactic function of a verb predicate. Enclitics are clitics that are attached to the end of basic verbs, both transitive and intransitive. As a result of adding cross-referencing addixes, both proclitic and enclitic, there is often a morphophonological process.

Morphophonological processes cannot be avoided because of the merging of one morpheme with another to form a new morpheme. The morphophonological processes in LDLL includes sound replacement as $/ \mathrm{g} /$ is replaced by $/ \mathrm{k} /$ and $/ \mathrm{m} /$ is replaced by $/ \mathrm{k} /$, insertion of sounds such as, /k/, /l/, /v/, /ng/, and zero changes as in enclitic singular third pronoun. Sound replacement and sound insertion is based on the similarity of phonological features and distinctive features. The similarity of phonological features such as similarities in the manner of articulation and point of articulation and the similarity of distinctive features such as consonantal, sonorant, anterior, and vowel characteristics. So, inflectional cases in LDLL are treated with clitics (proclitic and enclitic) while the morphophonological processes are handled phonologically.

\section{REFERENCES}

Alwi, Hasan dan Dendy Sugono. Ed. (2002). Telaah Bahasa dan Sastra. Jakarta:Yayasan Obo Indonesia

Chaer, Abdul. (2008). Morfologi Bahasa Indonesia (Pendekatan Proses).Jakarta:Rineka Cipta

Chaer, Abdul. (2013). Fonologi Bahasa Indonesia. Jakarta: Rineka Cipta

Demon, Yosef. (2006). Tipologi Sintaksis Bahasa Lamaholot Dialek Lamalera. (Tesis) Fakultas Ilmu Budaya, Universitas Udayana

Demon, Yosef. (2017). Struktur Klausa Bahasa Lamaholot Dialek Lamalera:Kajian Tipologi Sintaksis. (Disertasi) Fakultas Ilmu Budaya, Universitas Udayana Kridalaksana, 
Harimurti. (2009). Pembentukan Kata dalam Bahasa Indonesia. Jakarta: Gramedia Pustaka Utama

Linguistika. September. (2003). Vol 10. No.19 ISSN 0854-9163. Program Magister (S2) dan Doktor (S3) Universitas Udayana

Mathews, P.H. (1997). The Concise Oxford Dictionary of Linguistic. Oxford: Cambridge University Press

Masorong , S. K. (2021). The Meranaw Lexical Variants and its Implication to the Standardization of Meranaw Orthography. Randwick International of Education and Linguistics Science Journal, 2(2), 182-188. https://doi.org/10.47175/rielsj.v2i2.260.

Parera, J.D. (2007). Morfologi Bahasa. Jakarta:PT. Gramedia Pustaka Utama

Radford, A. (2004). Minimalist Syntax: Exploring the Structure of English. Cambridge: Cambridge University Press

Soedjito dan Djoko Saryono. Morfologi Bahasa Indonesia. (2014). Malang:Aditya Media Publishing

Sumadi. (2012). Morfologi Bahasa Indonesia. Malang: Universitas Negeri Malang 